Przynależność poszczególnych seminariów do rejonów oraz miejsce drugiego i trzeciego etapu będzie ustalone w zależności od zgłoszeń.

Księża profesorowie bibliści będą uprzejmi wypowiedzieć się na temat propozycji czy też sposobów przeprowadzenia samego konkursu. W przypadku zaś zgody na podjęcie pracy konkursowej $\mathrm{w}$ danym seminarium, proszeni są o łaskawe podanie adresu swego seminarium. Będziemy przesyłać potrzebne informacje i przekazywać je zainteresowanym alumnom.

Gościkowo-Paradyż

KS. TEOFIL HERRMANN CM

Ks. Tomasz Jelonek

\title{
SPRAWOZDANIE Z SYMPOZJUM BIBLISTÓW POLSKICH W ROKITNIE (1984)
}

Sanktuarium diecezji gorzowskiej w Rokitnie stało się miejscem dorocznego spotkania biblistów polskich w roku 1984. Sympozjum, które odbyło się w dniach 26 i 27 września, zgromadziło czterdziestu sześciu biblistów pracujących naukowo i dydaktycznie na uczelniach teologicznych i w Wyższych Seminariach Duchownych diecezjalnych i zakonnych.

Sympozjum stwarza okazję refleksji nad przemyśleniami, które ujęte w formę referatów i komunikatów przekazywane są zebranym i następnie uzupełniane w dyskusjach. Ta strona Sympozjum jest w jakiś sposób wymierna czasem referatów i ilością biorących udział w dyskusji. Sympozjum ma także inną stronę, której nie można wymierzyć i której także nie można ująć w sprawozdaniu, a jest nią spotkanie ludzi pracujących w podobnych warunkach nad słowem Bożym zapisanym w Biblii i nad biblijną formacją kapłanów oraz ludu Bożego. To spotkanie ludzi ubogaca ich samych i stwarza atmosferę, w której dokonują się prace Sympozjum przewidziane jego programem. O nich chcemy powiedzieć w tym krótkim sprawozdaniu.

Referatem wprowadzającym w tematykę Sympozjum był referat ks. prof. dr hab. Stanisława Grzy bk a na temat Metodologia teologii biblijnej. Prelegent przedstawił różne ujęcia tej dziedziny badań biblijnych, która jest szczególną refleksją człowieka wierzącego nad słowem Bożym. Zostały ukazane różne sposoby pojmowania roli teologii biblijnej i proponowane metody rozwiązywania jej zadań. W panoramie różnych opinii na temat, czym jest i jak ma postępować teologia biblijna, podkreślone zostały pozytywne elementy poszczególnych metod, a prelegent za najodpowiedniejszą uznał metodę diachroniczną G. von Rada, którą należałoby uzupełnić analizą typologiczną.

W czasie przedpołudniowych obrad pierwszego dnia Sympozjum wygłoszono jeszcze jeden referat, jeden komunikat naukowy i dwa komunikaty informacyjne. $\mathrm{Z}$ referatem na temat Problem interpretacji genealogii 1 Krn 1-9 wystąpił ks. prof. dr hab. Jan $⿱ ㇒ a c h$. Ta część Księgi Kronik poza komentarzami nie jest przedmiotem naukowych publikacji, a rodzi wiele pytań. Prelegent po przytoczeniu licznych danych odnoszących się do zestawów imion, podkreślił, że chociaż problem ich interpretacji pozostaje nadal otwarty, to jednak można stwierdzić, że rozważana część Księgi Kronik ma charakter teologiczny i przygotowuje dalszy ciąg Księgi. 
Genealogie podkreślają, że organizm społeczny i państwowy musi być zbudowany jedynie teokratycznie. Bóg bowiem, który wpleciony jest w ludzką historię i kieruje dziejami, obrał sobie Jerozolimę za swoją siedzibę, a naród ma dawać o Nim świadectwo.

Ks. doc. dr hab. Jerzy Chmiel wygłosił komunikat pod tytułem Propozycje egzegetyczne René Girarda. Uznając poglądy tego kontrowersyjnego filozofa i literata francuskiego jako wyzwanie dla egzegetów, prelegent próbował przeanalizować te elementy, które można przyjąć, oraz te, którym stanowczo trzeba się sprzeciwić. Kategorie bowiem wyprowadzone przez Girarda nie zgadzają się z właściwym przekazem biblijnym.

Referaty i komunikat wywołały ożywioną dyskusję, w której wzięło udział wielu uczestników Sympozjum. Szczególnie zajęto się problemem teologii biblijnej, starano się bardziej sprecyzować jej specyfikę i metody poznawcze. Między innymi O. prof. dr hab. Hugolin Lang ka m m e przewodniczący Sekcji Biblistów Polskich, podkreślił chrystoperspektywiczne patrzenie Starego Testamentu i chrystocentryzm w Nowym Testamencie. O. prof. dr hab. Augustyn Jankowski przypomniał o trzech zasadach objawienia biblijnego, jakimi są rozwój, ciągłość i transpozycja.

Informacyjny charakter miało wystapienie O. Profesora Jankowskiego, który zostal ponownie powołany do Papieskiej Komisji Biblijnej i o jej działalności oraz nowym składzie poinformował zebranych. Następnie ks. dr hab. Teofil Herrmann przedstawił zasady i organizacje międzyseminaryjnych konkursów biblijnych. Mają one pobudzać do zdobywania znajomości tekstów, wstępów umieszczonych w Biblii Tysiąclecia i przypisów.

Na sesję popołudniową złożyły się dwa referaty z dyskusją. W pierwszym ks. dr hab. Stanisław Potocki mówił na temat Metody kompozycji słów mędrców anonimowych (Prz 22, 17-24, 22). Ten zbiór wypowiedzi mądrościowych, stanowiący część Księgi Przysiów, jest zbiorem ważnym, ale mało studiowanym. Prelegent zaproponował jako klucz do rozważenia kompozycji zbioru zagadkowy termin szaliszîm $(22,20)$, wyrażający ideę troistości. Zastosowanie tego klucza pozwala w zbiorze wyróżnić trzy części. Pierwsza zdradzająca wpływy mądrości egipskiej, jest przestrogą przed działaniem na swoją szkodę, druga o karności serca kończy się satyrą na pijaństwo, tematem wiodącym części trzeciej jest mądrość.

W drugim referacie tej sesji ks. dr Roman Krawczyk przedstawił rolę pytania Kim jest człowiek? (Syr 18, 7) dla podstaw antropologii Księgi Syracha. W referacie zostały ukazane zbieżności terminologiczne i rzeczowe pomiędzy Księgą Syracha a trzema pierwszymi rozdziałami Księgi Rodzaju. Wynika z nich wniosek, że antropologia Syracha przedstawiona została na podstawie Ksieggi Rodzaju.

Skrócona sesja drugiego dnia Sympozjum składała się z jednego referatu ks. dr Andrzeja Kowalczyka pod tytułem Rola tematu wyjścia $z$ Egiptu $i$ podboju Ziemi Obiecanej w relacji Ewangelii św. Mateusza. Prelegent ukazał bardzo liczne podobieństwa rzeczowe i liczbowe pomiędzy Pięcioksięgiem i Księgą Jozuego a Ewangelią Mateuszową. Istnieją także podobieństwa między Ewangelią Mateuszową a Psalmem 107, nawiązującym do wyjścia z Egiptu, zwłaszcza jeżeli chodzi o ósmy i dziewiąty rozdział Ewangelii. Wnioskiem z tych rozważań było stwierdzenie, że tematy wyjścia i zdobycia Ziemi Obiecanej zdeterminowały Mateuszowe opowiadanie o Jezusie.

Referat wywołal ożywioną dyskusję, w której podkreślano skrupulatne wyliczenie podobieństw, ale również zastanawiano się, czy analogie były zamierzone przez hagiografa. Niewątpliwie ciekawy referat, oparty na wymagających dużego wysiłku badaniach, mógł budzić obawę w myśl zasady: qui nimis probat, nihil probat. 
Sympozjum Biblistów Polskich w Rokitnie miało także oprawę liturgiczną. Była nią przede wszystkim Msza święta koncelebrowana pod przewodnictwem ks. biskupa Pawła Sochy, biskupa pomocniczego w Gorzowie. Msza święta odprawiona została w pierwszym dniu obrad w sanktuarium Matki Bożej, która od 1669 roku w Rokitnie rozdziela swoje łaski. $\mathrm{Z}$ historią sanktuarium i kultu maryjnego zapoznali się uczestnicy Sympozjum wieczorem pierwszego dnia dzięki życzliwości miejscowego proboszcza, który podzielił się swoją rozległą wiedzą o miejscu, którego jest kustoszem.

W drugim dniu obrad uczestnicy koncelebrowali Mszę świętą w kaplicy domu rekolekcyjnego, który otworzył swoje gościnne progi dając biblistom miejsce na obrady, posiłki i spoczynek.

Po krótkim spotkaniu trzeba było wracać do swoich miejsc pracy, nowy bowiem rok akademicki był już ,za pasem".

Kraków

KS. TOMASZ JELONEK

\section{LISTA UCZESTNIKOW SYMPOZJUM}

1. ks. Roman Bartnicki - 00-498 Warszawa, Książęca 21

2. ks. Jerzy Chmiel - 31-003 Kraków, Podzamcze 8

3. ks. Edward Chmura - 37-700 Przemyśl, Zamkowa 5

4. ks. Paweł Cieślik - 71-730 Szczecin, Strzałkowska 26

5. ks. Michał Czajkowski - 00-132 Warszawa, Grzybowska 16/22 m. 912

6. ks. Jan Dyrda - 66-001 Zawada (diec. Gorzów)

7. ks. Stanisław Gądecki - 62-200 Gniezno, Seminaryjna 2

8. ks. Marian Gołębiowski - 87-800 Włocławek, Karnkowskiego 3

9. ks. Stanisław Grzybek - 30-066 Kraków, Beniowskiego 39

10. ks. Tadeusz Hanelt - 62-200 Gniezno, Seminaryjna 2

11. ks. Stanisław Hałas - 32422 Stadniki 81

12. ks. Tomasz Hergesel - 50-329 Wrocław, pl. Katedralny 14

13. ks. Teofil Herrmann CM - 66-203 Jordanowo (diec. Gorzów)

14. O. Augustyn Jankowski OSB - 30-375 Kraków, Benedyktyńska 37/39

15. ks. Tomasz Jelonek - 31-127 Kraków, Kochanowskiego 3/2

16. ks. Franciszek Jóźwiak - 87-800 Włocławek

17. ks. Andrzej Kowalczyk - 83-000 Pruszcz Gd., Wojska Polskiego 37

18. ks. Roman Krawczyk - 08-110 Siedlce, Swierczewskiego 64/4

19. ks. Józef Kudasiewicz - 20-039 Lublin, Nowotki 7

20. O. Hugolin Langkammer OFM - 20-039 Lublin, Nowotki 7

21. ks. Wiesław Lauer - 80-834 Gdańsk, Sw. Ducha 58

22. ks. Henryk Lempa - 50-328 Wrocław, św. Idziego 4/6

23. ks. Jan Each - Warszawa, Reymonta 10/238

24. ks. Michał Magda SVD - 14-520 Pieniężno, Kolonia 19

25. ks. Marek Major - 08-107 Paprotnia (diec. siedlecka)

26. ks. Stanisław Mędala - 00-047 Warszawa, Krakowskie Przedm. 3 
27. ks. Henryk Muszyński - 01-956 Warszawa, Wrzecionowo 52/154

28. ks. Leonard Pawlak FDP - 98-220 Zduńska Wola, Easka 88

29. O. Urban Pietrzyk OFM - 31-069 Kraków, Bernardyńska 2

30. ks. Stanisław Pisarek - 40-050 Katowice, Gen. Zajaczka 2

31. ks. Bogdan Poniży - 60-830 Poznań, Krasińskiego 11/2

32. ks. Stanisław Potocki - 37-700 Przemyśl, Zamkowa 5

33. ks. Jan Kanty Pytel - 60-348 Poznań, Skarbka 23

34. ks. Piotr Skucha - 25-013 Kielce, Swierczewskeigo 27

35. ks. Andrzej Strus - 99-300 Kutno - Woźniaków

36. ks. Edward Strycharz TCh - 61-120 Poznań, Lubrańskiego 1a

37. O. Damian Szojda - 40-760 Katowice, Panewnicka

38. ks. Andrzej Szewciw - 66-203 Jordanowo, Gościkowo-Paradyż

39. ks. Edward Szymanek TCh - 61-120 Poznań, Lubrańskiego 1a

40. ks. Antoni Tronina - 20-039 Lublin, Nowotki 7

41. ks. Julian Warzecha SAC - 05-850 Ożarów Maz. Ołtarzew,

Kilińskiego 20

42. ks. Henryk Witczyk - 25-013 Kielce, Swierczewskiego 27

43. ks. Marian Wittlieb - 72-200 Trzebiatów, Rybacka 2 (diec. Szczecin)

44. ks. Marian Wolniewicz - 61-109 Poznań, Mieszka I 9

45. ks. Stanisław Włodarczyk - 42-200 Częstochowa, św. Barbary 43

46. ks. Jan Załęski - 03-131 Warszawa, Mehoffera 2 